\title{
IIASA seeks new look
}

\section{Laxenburg, Austria}

The first post-Cold-War meeting of scientific experts on the environment was recently convened by the International Institute for Applied Systems Analysis, a product of the Cold War that is now seeking to secure its future as a leading centre for environmental and economic policy analysis.

Earlier this year, the US President, George Bush, approved a renewal of official US support for IIASA, eight years

\section{IMAGE UNAVAILABLE FOR COPYRIGHT REASONS}

Peter de Janosi - building on scientific strength.

after his predecessor, Ronald Reagan, cut US aid on the suspicion that the institute harboured Soviet spies. One of the conditions of the renewed US funding is that IIASA applies its skills in mathematical modelling to environmental research.

When IIASA was founded on the outskirts of Vienna in 1972, it was one of the few joint scientific initiatives between the United States and the Soviet Union. Ostensibly because IIASA may play an important role in the rebuilding of a democratic Eastern Europe, Bush has chosen to embrace the institute.

On the scientific side, IIASA has distinguished itself recently by producing the RAINS (Regional Acidification Information and Simulation) model of acidification caused by transboundary air pollution, which has been used in European negotiations. It will soon release a study on the impact of deforestation on the economy in Europe that it hopes will sway countries to do more to reduce harmful emissions.

The meeting of pollution experts demonstrates that IIASA is keen to move into the policy area, but to do this the institute will not only have to win heavy investment but also compete with an abundance of environmental and economic policy institutes in the West.

Nevertheless, the new US director,
Peter de Janosi, an economist with long experience at both the Ford Foundation and the Russell Sage Foundation, hopes to build on both the scientific strengths of the institute and its rapport with Eastern European countries - several of which are members - in attracting both good researchers and more financial support. "We're not some Western institution coming in to help the natives", says de Janosi, "We are the natives."

One recent example of this regional solidarity was a request from the southeastern European organization 'Pentagonale' asking IIASA to provide a regional inventory of air pollution on which political decisions in the five member states (Italy, Yugoslavia, Austria, Hungary and Czechoslovakia) can be based.

IIASA will also cooperate with the Regionai Environment Centre for Central and Eastern Europe in Budapest, a USbacked clearinghouse for environment information set up this past autumn.

De Janosi sees an opportunity for growth in contract research, which together with increases in dues from its member states could account for as much as a 25-30 per cent increase in IIASA's budget over his three-year term. The budget was 117 million schillings ( $\$ 12$ million) in 1989.

But he admits that this path to growth is perilous for an institute that wants to be a leader in basic research. "To get the best people", says de Janosi, "we of course have to let them do what they think is important."

For example, a delicate situation arose recently when the Soviet Union, one of the largest contributors, called upon IIASA to organize and carry out a quick review by Western and Soviet economists of Soviet economic reform plans. IIASA carried out the review gladly, said de Janosi, but he does not want the institute just to "fight fires". Instead, he said, he would prefer to try to understand economic transformation of planned economies in general with a special emphasis on the environment. But a more systematic approach, including examining the economies of other Eastern European countries, will have to wait, said de Janosi, until IIASA is specifically invited by those countries. Hiring more economists is also not yet on the cards.

Despite the popularity of the topic of global warming, IIASA intends to resist pressure to address more global or North-South issues in its research. "Our work will retain its regional focus", said de Janosi, "but it will occasionally touch on global issues."

One way to expand its research base is to seek new members from Western Europe, he said.
Steven Dickman
A new paymaster for UK science?

\section{London}

THE Royal Society should be given a greater role in the allocation of research grants, to ensure that young British scientists with alpha-rated research proposals actually get funded, according to its retiring president, Lord Porter. About half of all alpha-rated proposals are now turned down by the UK research councils, Porter says.

In his farewell address to the Royal Society on 30 November, Porter envisaged

\section{IMAGE UNAVAILABLE FOR COPYRIGHT REASONS}

Lord Porter - concerned about research councils' 'monopoly' over basic funding.

a new Science Foundation, operating at arm's length from the Royal Society, but drawing on the judgement of its thousand fellows to allocate grants. The Royal Society already distributes a small number of grants from its government grant-in-aid. This has risen by 50 per cent in real terms in the past two years, to $£ 14$ million in 1990-91, but a huge increase would be needed if Porter's aim of funding all alpharated research proposals is to be achieved. A new body should actually handle the money, Porter says, to preserve the Royal Society's jealously guarded independence from government.

Porter is concerned about the effective 'monopoly' that the research councils hold over basic science funding. A scientist whose highly rated research proposal is turned down by the research councils has nowhere to turn, apart from the Royal Society's own very limited programme, Porter says.

Porter would like his proposed Science Foundation to be given a new slice of government money, but accepts that the problem with British science is not just the absolute level of support, but also the way in which the money is spent.

The Science Foundation idea is Porter's own brainchild, rather than the Royal Society's. The incoming president, the mathematical physicist Sir Michael Atiyah, is so far noncommital. Any major changes in Royal Society policy will require careful

thought, he says.

Peter Aldhous 